Ricardo Gapski

Hom-Lay Wang

Paulo Mascarenhas

Niklaus P. Lang

\title{
Critical review of immediate implant loading
}

Key words: dental implant, immediate/early implant loading, osseointegration

Authors' affiliations:

Ricardo Gapski, Hom-Lay Wang, Paulo

Mascarenhas, Department of Periodontics/

Prevention/Geriatrics, School of Dentistry,

University of Michigan, Ann Arbor, MI, USA

Niklaus P. Lang, Department of Periodontology and

Fixed Prosthodontics, School of Dental Medicine,

University of Bern, Switzerland

\section{Correspondence to:}

Hom-Lay Wang

Professor and Director of Graduate Periodontics,

Department of Periodontics/Prevention/Geriatrics

University of Michigan School of Dentistry

IOI I North University Avenue

Ann Arbor

MI 48109-I078

USA

Tel: +17347633383

Fax: +I734 9360374

e-mail: homlay@umich.edu
Date:

Accepted 5 September 2002

To cite this article:

Gapski R, Wang H-L, Mascarenhas P, Lang NP. Critical

review of immediate implant loading.

Clin. Oral Impl. Res, I4, 2003; 5 I 5-527

Copyright $($ Blackwell Munksgaard 2003

ISSN 0905-7I 6 I

Abstract: Background: Implant dentistry has become successful with the discovery of the biological properties of titanium. In the original protocol, studies have advocated a 2-stage surgical protocol for load-free and submerged healing to ensure predictable osseointegration. However, the discomfort, inconvenience, and anxiety associated with waiting period remains a challenge to both patients and clinicians. Hence, loading implant right after placement was attempted and has gained popularity among clinicians. Issues/ questions related to this approach remain unanswered. Therefore, it is the purpose of this review article to (1) review and analyze critically the current available literature in the field of immediate implant loading and (2) discuss, based on scientific evidence, factors that may influence this treatment modality.

Material and Methods: Literature published over the past 20 years was selected and reviewed. Findings from these studies were discussed and summarized in the tables. The advantages and disadvantages associated with immediate implant loading were analyzed. Factors that may influence the success of immediate implant loading, including patient selection, type of bone quality, required implant length, micro- and macrostructure of the implant, surgical skill, need for achieving primary stability/control of occlusal force, and prosthesis guidelines, were thoroughly reviewed and discussed.

Results and Conclusion: Various studies have demonstrated the feasibility and predictability of this technique. However, most of these articles are based on retrospective data or uncontrolled cases. Randomized, prospective, parallel-armed longitudinal human trials are primarily based on short-term results and long-term follow-ups are still scarce in this field. Nonetheless, from available literature, it may be concluded that anatomic locations, implant designs, and restricted prosthetic guidelines are key to ensure successful outcomes. Future studies, preferably randomized, prospective longitudinal studies, are certainly needed before this approach can be widely used.

Dental implants have been widely used to retain and support cross-arch fixed partial dentures (Brånemark et al. I969; Brånemark et al. I977; Adell et al. I98I; Albrektsson et al. I986; Arvidson et al. I992; Albrektsson 1993; Astrand et al. I996). It has been advocated that after implant placement, surgical sites should be undisturbed for at least 3-6 months to allow uneventful wound healing, thereby enhancing osseointegration between the implant and bone (Adell et al. I98I). The rationale behind this approach is that implant micromovement caused by functional force around the bone-implant interface during wound healing may induce fibrous tissue formation rather than bone contact, leading to clinical failure (Adell et al. I98I). In addition, coverage of an implant has also been thought to prevent infection and epithelial downgrowth (Brånemark et al. I977; Brånemark et al. 
I985). Akagawa et al. performed an animal study comparing two types of implants: one was submerged and the other was projecting into the oral cavity approximately $9 \mathrm{~mm}$ (Akagawa et al. I986). Histological observation showed direct bone apposition next to the submerged implants, while the nonsubmerged implants had connective tissue at the apical portion. The authors concluded that initial exposure/biomechanical stimuli often induced a fibrous connective tissue interface between implants and bone. Hence the submerged implants were preferable for the initial rigid fixation. However, certain problems/concerns remain when this 2stage surgical protocol was used. These include: avoiding any prosthesis for a minimum of 2 weeks to promote uneventful healing; loose denture, pain, difficulty with chewing during transitional removable prosthesis wearing period (Schnitman et al. I997); and the necessity of additional surgery to expose implant fixtures. These concerns have commonly caused physiological, psychological, or sociological challenges for patients who underwent implants treatment (Salama et al. I995). Therefore, focus on loading implants soon after their placement has been attempted and has gained some acceptance among clinicians, but the results are not conclusive.

Animal studies have been conducted to test the feasibility of achieving osseointegration while loading implants right away. Early studies have shown conflicting results. Some reported that loading implants immediately jeopardizes osseointegration (Uhthoff I973; Schatzker et al. I975; Akagawa et al. I986) and promotes fibrous tissue encapsulation (Brunski et al. I979). Others have observed direct bone-toimplant contact (BIC) with newly designed screw implants as well as when coated implant surfaces were used (Sagara et al. I993). However, the authors also found more crestal bone loss in the loaded I-stage implant group when compared to the 2-stage unloaded control group. It was speculated that the early occlusal loading during healing may account for this observation since early loading may interfere with the ability of new bone being formed to restore the necrotic bone at the implant/ bone interface usually occurring from surgical trauma (Albrektsson et al. I98I). Similar findings were also reported in non-human primates (Lum \& Beirne I986). Later animal data indicated that osseointegration could be accomplished in immediately loaded implants regardless of the type of surface coating (Lum \& Beirne I986; Evans et al. I996; Piattelli et al. I997a; Corso et al. 1999; Romanos et al. 2001).

In fact, earlier results with immediate implant loading were often unpredictable (Schnitman \& Shulman I980; Rosenlicht I993). Fibrous encapsulation around implants was a common finding due to a variety of reasons such as poor implant materials/designs, lack of understanding the mechanical aspect of implant loading and others (Strock \& Strock I939; Hodosh et al. 1969; Linkow et al. I973; Piliero et al. I973; Cross et al. I974; Listgarten \& Lai I975; Brunski et al. I979). With the introduction of I-stage implants, improvement in implant design (e.g., screw shape), and development of roughened implant surfaces (e.g., plasma-coated implant, hydroxyapatite (HA)-coated implants) and better force management/understanding (e.g., cross-arch stability) have all made this concept of immediate implant loading possible. Studies in the area of immediate loading have been proposed and have shown encouraging results (Buser et al. I988; Piattelli et al. I993; Henry \& Rosenberg I994; Salama et al. I995; Bijlani \& Lozada I996; Chiapasco et al. I997; Piattelli et al. I997a, I997b, I998; Tarnow et al. I997; Randow et al. I999; Scortecci I999; Ericsson et al. 200ob; Gatti et al. 2000; Horiuchi et al. 2000; Jaffin et al. 2000; Malo et al. 2000; Colomina 200I; Cooper et al. 200I; Ganeles et al. 200I). However, the achievement of predictable outcomes is dependent on certain principles. These principles have been largely based on clinical experience rather than scientific-based data. Therefore, the objectives of this paper are to (I) critically review and analyze currently available literature in the field of immediate implant loading, and 2) discuss, based on scientific evidence, factors that may influence this treatment modality.

\section{Material and Methods}

A Medline search was performed and the most valuable and relevant articles were selected. Studies involving I-stage surgical placement were included only if the fix- tures were immediately or early loaded (within 3 weeks) after placement. Case reports with few samples were only utilized if they presented unique information that was not demonstrated in major retrospective or prospective trials. Only the data from human studies were evaluated and presented. It is the intent of this paper to include the most valuable information of each paper as well as to critically assess their methodology. In the discussion, data is organized to address factors that had significant support on immediate implant loading. These include surgery-, host-, implant-, and occlusal-related factors. A summary from these reviews was then concluded.

\section{Results}

High success rates from immediately loaded implants in humans were first documented in the middle I980s, when the I-stage implant protocol gained popularity. Babbush et al. (1986) reported a cumulative success rate of $88 \%$ on 1739 immediately loading TPS implants. Subsequently, many authors have shown the possibility of loading implants immediately (Buser et al. I988; Piattelli et al. I993; Henry \& Rosenberg I994; Salama et al. I995; Bijlani \& Lozada I996; Chiapasco et al. I997; Piattelli et al. I997a, I997b, I998; Tarnow et al. I997; Randow et al. I999; Scortecci I999; Ericsson et al. 2000b; Gatti et al. 2000; Horiuchi et al. 2000; Jaffin et al. 2000; Malo et al. 2000; Colomina 200I; Ganeles et al. 200I). Early implants loaded (within 3 weeks) were also shown to be highly predictable. A prospective multicenter study reported a resultant of $96.2 \%$ survival rate of 53 fixtures placed in 47 patients, I 2 months after placement (Cooper et al. 200I). However, this paper will only discuss the immediately loaded implant studies.

Henry \& Rosenberg (I994) reported 2-year clinical results using a single-stage surgical protocol in conjunction with controlled immediate loading. They suggested that clinical performance and prognosis of the procedure were comparable to the traditional 2-stage method (e.g., allowing time for implant healing without any interference from occlusal contact). Schnitman et al. (I997) observed 6I implants 
placed in Io patients. Out of these 6I implants, 28 were placed and immediately loaded to support an interim fixed bridge. A success rate of $85 \%$ was reported in immediately loaded implants compared to Iо० \% for submerged unloaded implants. However, it should be noted that $30 \%$ of immediately loaded implants were connected with natural teeth and that no more than 3 implants were used to support an interim fixed partial denture. In addition, the force distribution between test and control was also different. Therefore, results of this trial should be interpreted with caution. However, it illustrates that it is possible to achieve long-term success when implants are placed in function even in their earlier stage.

Tarnow et al. (I997) placed a minimum of ro implants with half of them being submerged to load free healing. Subsequently, more implants were loaded immediately in the last four patients. Totally, 69 implants were immediately loaded and 38 were submerged without loading. Almost 97\% (IO4/IO7) were successfully integrated. One submerged implant failed due to infection that spread from the adjacent extraction socket. Two immediately loaded implants were lost when the cemented provisional restoration was tapped off to verify healing. Interestingly, no difference was found between maxillary and mandibular implants.

Bijlani \& Lozada (1996), in a retrospective study, evaluated the success rate of immediately loaded implants placed in four patients after 3-6 years of clinical function. All implants placed and loaded immediately were successfully osseointegrated, according to the criteria described by Albrektsson (I986). It is important to note that patients in this study received complete removable prostheses in the maxilla and soft-tissue-supported overdentures in the mandible (Bijlani \& Lozada I996). This suggests that the occlusal scheme may be another key factor for a successful outcome with immediately loaded implants. This was later confirmed by Balshi \& Wolfinger (I997), who found that $75 \%$ of failures in immediately loaded implants occurred in patients with bruxism. In this study, I 30 implants were placed in Io patients, 40 being immediately loaded and 90 left submerged, according to the second-stage protocol. Results after I2-I 8 months showed a survival rate of $80 \%$ for immediately loaded implants, while unloaded implants had an average of $96 \%$ success rate.

A multicenter retrospective study was conducted by Chiapasco et al. (I997) on 226 patients with a mean follow-up period of 6.4 years (ranging from 2 to $\mathrm{I} 3$ years). Totally, 904 immediately loaded implants had been placed between the interforaminal area of the mandibular symphysis (4 implants per patient). Thirty-two patients did not complete the study for unknown reasons. The overall failure rate of immediately loading implants was very small (3.1\%). Randow et al. (I999) further compared the oral rehabilitation of edentulous mandibles with fixed implant prostheses using either a I-stage immediate loading or a 2-stage unloaded protocol. For the unloaded cases, dentures were not used for the first Io days and a relining of the original denture was placed in function after this period. Results showed no difference between the 2 groups examined after I 8 months. The survival rate for both groups was I00\%. Scortecci et al. (1999) placed 783 titanium implants $(627$ laterally inserted disk implants, with or without 156 axially inserted structure implants). Implants were evaluated using Periotest ${ }^{\circledR}$ and torque testing at $20 \mathrm{~N} \mathrm{~cm}$. They found that $98 \%$ of immediately loaded implants were considered osseointegrated after 6-48 months. The authors attributed their high long-term success to the unique implant design, which allows better stress distribution to ensure long-term success.

Gatti et al. (2000) evaluated long-term results of immediately loaded implantretained overdentures supported by 4 TPS screw implants. Overdentures were supported by 4 implants and bar clips were immediately placed. A cumulative survival rate of $96 \%$ was reported in I9 patients who were followed for 25 months. Chiapasco et al. (200I) compared the success rate of immediately loaded vs. delayed loaded implants in 20 patients with implant-retained mandibular overdentures and demonstrated a similar success rate, $97.5 \%$ for both groups. Another study utilizing Brånemark fixtures has also obtained a high success rate $(98.3 \%)$ in edentulous mandibles (Chow et al. 2001). A similar success rate was also achieved in a new protocol for immediately loaded implant treatment (Brånemark et al. I999). In this study, I 50 implants were placed in 50 patients. The proposed guidelines involve prefabricated components and surgical guides, elimination of the prosthetic impression procedure, and placement of a permanent bridge on the day of implant placement.

Results from these studies clearly suggest that implant immediate loading could achieve equal success rates as those found in delayed or unloaded implants.

Few studies have focused on immediate loading of implants for single-tooth replacement (Gomes et al. I998; Ericsson et al. 2000a; Malo et al. 2000; Chaushu et al. 200I; Cooper et al. 200I). Gomes et al. (I998) placed HA-coated implant and loaded immediately with a provisional crown. Clinically, the implants showed no mobility and remained in function for the duration of the study. However, it should be noted that the restoration was removed from any centric and lateral occlusal contacts. Malo et al. (2000) investigated 94 Brånemark implants that were immediately loaded. This retrospective study indicated a cumulative survival rate of $96 \%$ ( 6 months to 4 years). Ericsson et al. $(2000)$ reported the failure of 2 out of $\mathrm{I} 4(\mathrm{I} 4 \%)$ immediately loaded single implants vs. no failure in single implants placed in the 2-stage protocol (8 out of 8 ). Implants were loaded via temporary crowns within $24 \mathrm{~h}$. More recently, Chaushu et al. (200I) compared immediately loaded implants placed in fresh extraction sites to that of healed sites in 26 patients. The survival rates were $82 \%$ and I00\% respectively. This implies that immediate loading of single-tooth implants placed in fresh extraction sites may carry a risk of failure in $\mathrm{I} / 5$ of fixtures. On the contrary, Jo et al. (200I) demonstrated a $98.9 \%$ success rate for implants placed in fresh extraction sockets and immediately loaded. The authors attributed this favorable result to the system used, an expandable implant. It is understandable that the occlusal scheme favors the placement of single immediate loading implants for tooth replacement compared to fully edentulous situations, since adjacent natural teeth may protect implant prostheses from occlusal trauma during early phases of healing. However, the hypothesis remains to be proven. 


\section{Discussion}

The majority of immediate implant loading studies reported similar success rates when compared to the traditional 2-stage approach (Buser et al. I988; Piattelli et al. 1993; Henry \& Rosenberg 1994; Salama et al. 1995; Bijlani \& Lozada 1996; Chiapasco et al. 1997; Tarnow et al. 1997; Randow et al. 1999; Scortecci 1999; Gatti et al. 2000; Horiuchi et al. 2000; Jaffin et al. 2000; Malo et al. 2000; Colomina 200I; Cooper et al. 200I; Ganeles et al. 200I). Nonetheless, these findings do not imply that submerged wound healing is no longer necessary. Future studies are needed to identify the appropriate indications that may suit either approach. Data from the current available literature already suggest that several factors may influence the results of immediate implant loading. These could be divided into the following four categories: surgery-, host-, implant-, and occlusion-related factors. Surgical factors consist of primary implant stability and surgical technique. Host factors comprise the quality and quantity of cortical and trabecular bone, wound healing, and modeling/remodeling activity. Implant factors include designs, surface textures, and dimensions of the implant. Occlusal factors involve the quality and quantity of force and prosthetic design. These factors are further discussed in the following sections.

\section{Surgery-related factors Primary implant stability}

Of all factors involved, primary stability seems to be the most important determining factor on immediate implant loading. Functional loading placed on an immobile implant is an essential ingredient to achieve osseointegration (Roberts et al. I984). If an implant is placed in the soft spongy bone with poor initial stability, it often results in the formation of connective tissue encapsulation, similar to the pseudoarthrosis observed in an unstabilized fracture site (Brunski et al. 1979; Schroeder et al. I98 I; Hansson et al. 1983; Spector 1988; Albrektsson \& Sennerby I99I; Aspenberg et al. I992; Roberts 1993; SzmuklerMoncler et al. 1998). Micromovements of more than Ioo $\mu \mathrm{m}$ are sufficient to jeopardize healing with direct BIC (Brunski
I993). This observation was also reported by Szmukler-Moncler et al. (1998), who indicated that micromotions at the boneimplant interface beyond $\mathrm{I} 5 \mathrm{O} \mu \mathrm{m}$ resulted in fibrous encapsulation instead of osseointegration. It can be further speculated that these movements would be detrimental in cases with immediate implant loading.

Some authors hypothesized that immediately loaded implants must engage dense cortical bone both at apical and crestal aspects to ensure extra stability (Chiapasco et al. I997; Schnitman et al. I997). However, a retrospective study reported that a bicortically anchored implant in the maxilla failed almost 4 times more than monocortically stabilized implants (Ivanoff et al. 2000). It is also important to note that the assessment of mono- vs. bicortical stabilization in this study was performed on pantographs and most of the causes of failure were fractures $(\sim 80 \%)$. Prosthetic misfit and unfavorable occlusal/stress factors might have also influenced the outcomes and, therefore, the data should be interpreted with caution. Biomechanically, the concept of bicortical placement is certainly valuable since the higher surface of the fixture is engaged in compact bone. Further prospective studies need to be conducted to evaluate this hypothesis.

In summary, when primary stability is achieved and a proper prosthetic treatment plan is followed, immediate functional implant loading is a feasible concept. However, if the primary fixture stability cannot be achieved or is questionable, it is strongly recommended to follow a conventional treatment protocol including an adequate healing time before loading.

\section{Surgical technique}

Gentle surgical placement is also a key element for implant success regardless of the applied treatment protocol. Excessive surgical trauma and thermal injury may lead to osteonecrosis and result in fibrous encapsulation of the implant (Satomi et al. I988). Heat generated during drilling without adequate cooling is associated with bone damage (Eriksson et al. 1982; Eriksson \& Albrektsson 1984; Eriksson et al. I984a; Eriksson et al. I984b). It has been shown that a temperature over $47^{\circ} \mathrm{C}$ for I min causes 'heat necrosis' in the bone (Eriksson \& Albrektsson 1983). Without irrigation, drill temperatures above $100^{\circ} \mathrm{C}$ are reached within seconds during the osteotomy preparation, and consistent temperatures above $47^{\circ} \mathrm{C}$ are measured several millimeters away from the implant osteotomy (Yacker \& Klein I 996). In addition, it is critical for the success of endosseous rootform implants that adequate load be placed on the drill during the preparation of osteotomies. It has been demonstrated that independently increasing either the speed or the load caused an increase in temperature in bone. Interestingly, increasing both the speed and the load together allowed for more efficient cutting with no significant increase in temperature (Brisman I996). Other factors related to heat generated into bone include amount of bone prepared (Eriksson et al. I984a), drill sharpness and design (Matthews \& Hirsch 1972; Wiggins \& Malkin 1976; Eriksson et al. I984b), depth of the osteotomy (Babbush \& Shimura 1993; Haider et al. 1993), and variation in cortical thickness (Hobkirk \& Rusiniak 1977; Eriksson \& Albrektsson 1984). It is shown that implant surgery generates microfractures in the surrounding bone, especially when press-fitting is intended. These fractures heal according to the following cascade: angiogenesis, osteoprogenitor cell migration, woven bone scaffold formation, deposition of parallelfibered or lamellar bone, and secondary bone remodeling (Schenk \& Hunziker I994).

When a proper surgical/prosthodontic technique is followed, the crestal bone loss around immediately loaded implants seems to be in the normal range when compared to a submerged protocol (Brånemark et al. 1999; Randow et al. 1999; Ericsson et al. 2000a; Ericsson et al. 2000b). Crestal bone loss was found to be $0.14 \mathrm{~mm}$ in immediately loaded implants vs. $0.07 \mathrm{~mm}$ in the delayed approach in a period between 6 and I 8 months (Ericsson et al. 2000a). Cooper et al. (200I) reported a mean change in marginal bone level of $0.4 \mathrm{~mm}$ at I2 months in single early loaded implants. Chow et al. (200I) later showed a mean marginal bone loss of $0.6 \mathrm{~mm}$ in a prospective study up to 30 months of immediately loaded implants. It is important to note that operator experience in implant dentistry may also indirectly influence the outcome of the treatment. Previous studies have reported an implant failure rate that was 
almost twice that of more experienced clinicians who had placed more than 50 implants (Lambert et al. I997; Morris et al. I997).

\section{Host-related factors}

Bone quality \& quantity

Histological data on immediately loaded implants have demonstrated not only a direct BIC, but also a favorable bone quality around the fixtures (Piattelli et al. I993; Henry et al. I997; Piattelli et al. I997a; Piattelli et al. I998; Romanos et al. 200I). Although favorable histological data have been documented, the clinical determination of successful immediately loaded implant remains a challenge. Clinically, host bone density plays an important role in determining the predictability of the immediate implant loading success. An implant placed in compact dense bone is more likely to ensure initial stability and, hence, better able to sustain such immediate forces. Resonance frequency analysis indicated that implants are as stable at the time of placement as when measured at 3-4 months postsurgery, when placed into dense bone (Friberg et al. I999). These results support the concept of direct loading of implants when inserted in the mandibular interforaminal regions. Therefore, this homologous, dense bone type may present several advantages for immediate loading implant dentistry. The cortical lamellar bone may heal with little interim woven bone formation, ensuring good bone strength while healing next to an endosteal implant (Roberts et al. I987; Roberts I993). In addition, its fine porosity ( $\leq \mathrm{IO} \%$ ) favors better mechanical interlocking compared to soft cancellous bone, which reaches $80-95 \%$ porosity (Schenk \& Hunziker I994). In fact, studies have shown that less dense bone may cause higher implant failure, even when a secondstage protocol is followed (DeAngelis I970; Brånemark et al. I985; Engquist et al. I988; Schnitman et al. I988; Jaffin \& Berman I99I). Jaffin \& Berman (I99I) evaluated retrospectively the success rate of I054 implants placed in different bone densities. Of implants placed in type I-III bone, only $3 \%$ of fixtures were lost; of the IO \% of fixtures placed in type IV bone with a thin cortex and poor medullary strength due to low trabecular density, 35\% failed. Therefore, due to its favorable mechanical properties, a majority of studies involving premature/early loading were conducted in the anterior mandible, where dense bone is usually found (Roberts et al. I984; Lefkove \& Beals I990; Piattelli et al. I998; Ganeles et al. 200I). A review of the literature demonstrated that $72 \%$ of cases placed in this region are either in DI or D2 quality bone (Misch I999a).

As mentioned earlier, fine trabecular bone presents the most arduous endeavor to obtain rigid fixation, no matter which implant is used. For the reasons just mentioned, this type of bone may be unsuitable for immediate loading implant techniques. Interestingly, few human reports have shown similar predictability regardless of anatomic location (Salama et al. I995, Tarnow et al. I997, Horiuchi et al. 2000). Levine et al. (I998) placed io implants in the maxilla / 3 loaded immediately and 7 followed 2-stage protocol) and showed that all implants osseointegrated after 2 years. Horiuchi et al. (2000) also reported no difference in the success rate between arches in immediate loading implants in I4 patients. In this case series, 44 implants were placed in the maxilla and 96 in the mandible, providing a success rate of $95.5 \%$ and $97.9 \%$, respectively. A multicenter prospective study involving single and partially fixed prosthesis in 93 patients with I42 implants also demonstrated no difference in success rates between maxilla and mandible (Buchs et al. 200I). In this trial, a temporary prosthesis was constructed from nonheat-generating material and temporarily cemented into place. Within the limited available information, it appears that primary stability, more than the arch (anatomic) location, may be the fundamental requirement for immediate implant loading techniques. On the other hand, there has been no unanimous protocol to be followed regarding bone density and number of implants, or type of prosthesis to be used in immediate loading cases. In addition, a majority of implants placed in different jaw locations/ type of bone will not require identical healing periods. For this reason, clinicians should utilize this protocol mainly in areas where dense bone is located and where primary stability can be achieved. Studies on softer/cancellous bone have been scarce; therefore, further studies are needed to understand the immediately loaded pre- dictability function in this type of anatomic location.

\section{Wound healing}

Metabolic diseases that directly affect bone metabolism such as osteoporosis/osteopenia or hyperparathyroidism may significantly influence implant wound healing. Osteoporosis, a pathology process leading to an absolute decrease in bone mass, has risen rapidly in the population, and poses a major public health problem (Riggs \& Melton 1986). Although animal research has commonly shown impairment of bone formation around implants in osteoporotic specimens (Mori et al. I997; Hara et al. I999; Yamazaki et al. I999; Lugero et al. 2000), human trials have demonstrated that dental implant placement in patients diagnosed with osteoporosis may be successful over a period of many years if an extended healing period is advocated (Dao et al. 1993; Fujimoto et al. 1996; Becker et al. 2000; Friberg et al. 200I). So far, no attempt has been made in loading implants immediately in patients who are diagnosed with systemic diseases such as diabetes and hyperparathyroidism as well as smokers. A similar situation is also true for patients who have undergone radiation therapy. Therefore, it is strongly suggested to follow the standard 2-stage protocol or even utilize longer periods of healing in patients diagnosed with these disorders. The same standard guidelines are suggested to be used in smokers or patients under radiation therapy on the oral cavity, until future research proves otherwise. Prior to surgery, a medical consultation and thorough explanation of possible risks to patients should be mandatory.

Under optimal conditions (atraumatic surgery), it has been demonstrated that only after 6 weeks of implant placement, lamellar bone was present at or near the implant surface (Roberts et al. I984). The surrounding bone heals according to the cascade mentioned earlier: angiogenesis, osteoprogenitor cell migration, woven bone scaffold formation, deposition of parallelfibered or lamellar bone, and secondary bone remodeling (Schenk \& Hunziker I994). Although there is no quantitative data for the early healing process in humans, it is reasonable to assume that loading of implants immediately after their 
placement would involve certain biological risks, since the initial healing process is still ongoing. Interestingly, histological animal data for implants immediately loaded have actually shown no adverse effects in either the osseointegration process or the bone morphology around the fixtures (Piattelli et al. I 993; Henry et al. I997; Piattelli et al. I997a; Piattelli et al. I998; Romanos et al. 200I). In fact, some data have demonstrated that early load increased BIC and allowed a faster remodeling process when compared to unloaded controls (Piattelli et al. I997a; Piattelli et al. I993; Piattelli et al. I998). This concept of the mechanical stimulation of bone around implants was also evaluated and confirmed by Rubin and McLeod. In this animal study, data demonstrated that brief exposure to extremely low-amplitude mechanical strains could enhance the biologic fixation of cementless implants (Rubin \& McLeod I994). In conclusion, it can be speculated that immediate loading of dental implants may accelerate bone formation, but it is also imperative to state that primary stability is essential for this process to occur.

\section{Implant-related factors Implant design/configuration}

Implant configuration has long been considered as an essential requirement for implant success. As a general concept, the screw implant design develops higher mechanical retention as well as greater ability to transfer compressive forces (Skalak I985; Wolfe \& Hobkirk I989; Lefkove \& Beals I990; Randow et al. I999). The screw design not only minimizes micromotion of the implant but also improves the initial stability, the principal requirement for immediate loading success. Additionally, the thread increases surface area (Misch I999c). Studies have shown the absence of fibrous tissues at the interface of screwshaped implants, even if they are loaded immediately after insertion (Skalak I985; Wolfe \& Hobkirk I989). Hence, due to its mechanical retention properties, it is generally recommended to use threaded-type implants for immediate loading cases. It is also important to note that favorable clinical outcome with cylinder-type implants has been documented when a delayed loading regimen was employed (Wheeler I996). However, the cylindertype implant would appear contraindicated for immediate or early loading regimens due to lowering of primary stability and less resistance to vertical movement and shear stress.

\section{Implant surface coating}

Rough implant surfaces render a significant increase of BIC (Buser et al. I99I; Wennerberg et al. I995; Trisi et al. I999). The shear strength of implants with a rough surface was shown to be about 5 times as high as that of implants with a smooth surface ( $\mathrm{Li}$ et al. I999). In addition, greater forces are required to remove implants with a rougher surface compared to implants with a smoother surface (Wennerberg et al. I995). Despite these advantages, animal and human studies involving immediate loading placement have tended to show no significant differences in implant success when surface coating types are analyzed (Piattelli et al. I993; Evans et al. I996; Piattelli et al. I997b; Corso et al. I999). Human histological data reported by Piatelli et al. (I993, I997b) showed that a mature, compact, cortical bone was formed around the immediately loaded implant, with $60-90 \%$ BIC. Similar results were also documented in 2 immediately loaded osseotite implants retrieved after 4 months (Testori et al. 200I). Although the critical BIC to guarantee implant success has not been defined, these findings are in agreement with the amount of BIC reported in most studies where a 2-stage protocol was utilized. Tables I-3 list current human studies in the field of immediate loading.

The reason for clinical success regardless of implant surface coating may be due to the type of bone utilized in a majority of human trials. As mentioned before, most of the studies have focused on using the anterior mandible, where the densest bone is located. It seems to suggest that the initial mechanical interlocking between

Table 1. Human studies: edentulous-bar type

\begin{tabular}{|c|c|c|c|c|c|c|c|c|}
\hline \multirow[t]{2}{*}{ Author } & \multirow[t]{2}{*}{ Period } & \multicolumn{3}{|c|}{ System } & \multirow{2}{*}{$\begin{array}{l}\text { Number of } \\
\text { patients }\end{array}$} & \multirow{2}{*}{$\begin{array}{l}\text { Number of } \\
\text { implants }\end{array}$} & \multirow{2}{*}{$\begin{array}{l}\text { Immediate } \\
\text { loading } \\
\text { success } \\
\text { rate }(\%) \\
\end{array}$} & \multirow{2}{*}{$\begin{array}{l}\text { Delayed } \\
\text { loading } \\
\text { success } \\
\text { rate }(\%) \\
\end{array}$} \\
\hline & & Brand & $\begin{array}{l}\text { Size } \\
(\mathrm{mm})\end{array}$ & Design & & & & \\
\hline Brånemark et al. (1999) & $\begin{array}{l}\text { Prospective } \\
\quad 6 \text { months- } 3 \text { years }\end{array}$ & Brånemark & 13 & $\mathrm{~T}$ & 50 & $150 \mathrm{IL}$ & 98 & - \\
\hline \multirow[t]{2}{*}{ Spiekermann et al. (1995) } & $\begin{array}{l}\text { Retropective Mean } \\
5.4 \text { years }\end{array}$ & ITI & - & T/TPS & 136 & $36 \mathrm{IL}$ & 97.2 & - \\
\hline & & $\mathrm{IMZ}$ & & C & & $164 \mathrm{DL}$ & $\sim 89$ & \\
\hline \multirow[t]{4}{*}{ Chiapasco et al. (1997) } & Retrospective & ITI & $12.6^{*}$ & $\mathrm{~T}$ & 226 & $152 \mathrm{IL}$ & Overall & - \\
\hline & & ITI & $13.9^{*}$ & T/TPS & & $380 \mathrm{IL}$ & 96.9 & \\
\hline & & Mathys & $15.8^{*}$ & $\mathrm{~T} / \mathrm{Ha}-\mathrm{Ti}$ & & $208 \mathrm{IL}$ & & \\
\hline & & Friatec & $14.2^{*}$ & $\mathrm{~T} / \mathrm{NLS}$ & & $164 \mathrm{IL}$ & & \\
\hline Chiapasco et al. (2001) & $\begin{array}{l}\text { Prospective } \\
24 \text { months }\end{array}$ & Brånemark & $>13$ & $\mathrm{~T} / \mathrm{M}$ & 20 & $\begin{array}{l}40 \mathrm{IL} \\
40 \mathrm{DL}\end{array}$ & 97.5 & 97.5 \\
\hline Babbush et al. (1986) & $\begin{array}{l}\text { Retrospective } \\
1-96 \text { months }\end{array}$ & ITI & - & T/TPS & 484 & $1739 \mathrm{IL}$ & 87.9 & - \\
\hline Gatti et al. (2000) & $\begin{array}{l}\text { Prospective } \\
25-60 \text { months }\end{array}$ & ITI & $10-14$ & T/TPS & 21 & $84 \mathrm{IL}$ & 96 & \\
\hline
\end{tabular}

IL, immediate loaded; DL, delayed loaded; EL, early loaded (within 3 weeks); HC, hollow cylinder; HS, hollow screw; T, threaded; M, machined; C, Cylinder. *Mean length. 


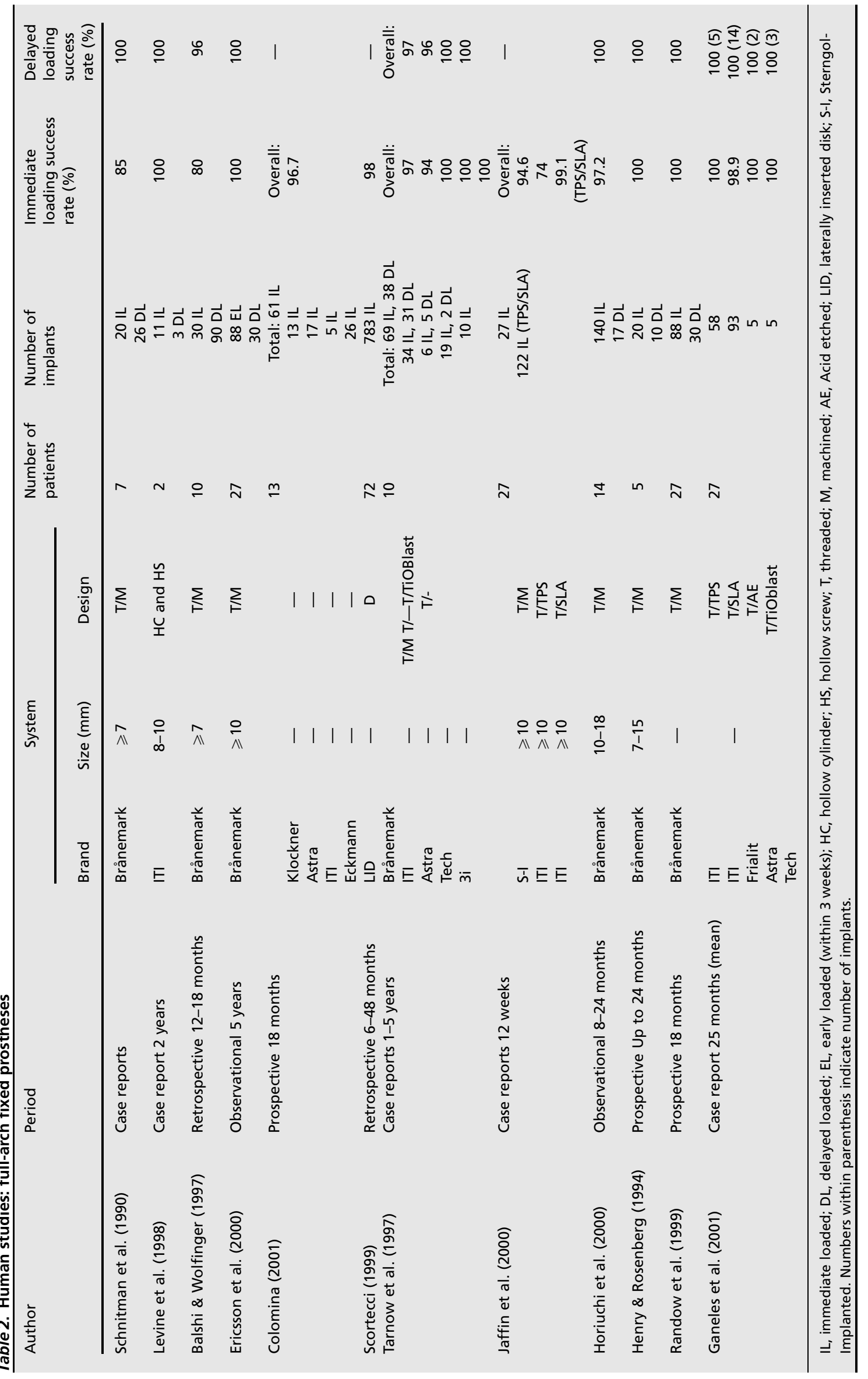


Table 3: Human studies: partially edentulous (including single tooth replacement)

\begin{tabular}{|c|c|c|c|c|c|c|c|c|}
\hline \multirow[t]{2}{*}{ Author } & \multirow[t]{2}{*}{ Period } & \multicolumn{3}{|c|}{ System } & \multirow{2}{*}{$\begin{array}{l}\text { Number of } \\
\text { patients }\end{array}$} & \multirow{2}{*}{$\begin{array}{l}\text { Number of } \\
\text { implants }\end{array}$} & \multirow{2}{*}{$\begin{array}{l}\text { Immediate } \\
\text { loading } \\
\text { success } \\
\text { rate }(\%) \\
\end{array}$} & \multirow{2}{*}{$\begin{array}{l}\text { Delayed } \\
\text { loading } \\
\text { success } \\
\text { rate }(\%) \\
\end{array}$} \\
\hline & & Brand & $\begin{array}{l}\text { Size } \\
(\mathrm{mm})\end{array}$ & Design & & & & \\
\hline Malo et al. (2000) & $\begin{array}{l}\text { Retrospective } \\
6 \text { months- } 4 \text { years }\end{array}$ & Brånemark & $10-18$ & $\mathrm{~T} / \mathrm{M}$ & 49 & $94 \mathrm{IL}$ & 96 & \\
\hline Ericsson et al. (2000) & Prospective 18 months & Brånemark & $\geqslant 13$ & $\mathrm{~T} / \mathrm{M}$ & 22 & $\begin{array}{l}14 \mathrm{IL} \\
8 \mathrm{DL}\end{array}$ & 86 & 100 \\
\hline Buchs et al. (2001) & Perspective & NTR & $>10$ & $\mathrm{~T} / \mathrm{M}$ & 93 & $142 \mathrm{IL}$ & 93.7 & \\
\hline Gomes et al. (1998) & Case report 6 months & Replace & 16 & $\mathrm{~T} / \mathrm{HA}$ & 1 & $1 \mathrm{IL}$ & 100 & \\
\hline Chow et al. (2001) & Prospective $3-30$ months & Brånemark & $>7$ & $\mathrm{~T} / \mathrm{M}$ & 27 & $115 \mathrm{IL}$ & 98.3 & \\
\hline Jo et al. (2001) & Prospective 40 months & Sargon & $>10$ & $\mathrm{~T} / \mathrm{M}$ & 75 & $\begin{array}{l}246 \mathrm{IL} \\
40 \mathrm{DL}\end{array}$ & 96.3 & 90 \\
\hline
\end{tabular}

IL, immediate loaded; DL, delayed loaded; HC, hollowcylinder; HS, hollowscrew; C, cylinder; M, machined; T, Threaded; NTR, natural tooth replacement.

threads and dense bone may overcome the beneficial properties that each coating type provides. In fact, peak insertion torque and resonance frequency values demonstrated similar implant primary stability regardless of surface type when placed in type II and III bone (O'Sullivan et al. 200o). The same parameters showed that thread design was more of a determinant than surface characteristics for primary stability into softer type IV bone (O'Sullivan et al. 2000). Future studies should still be conducted in regions with softer bone to evaluate if implant surfaces play a relevant role in immediate implant loading success.

\section{Implant length}

The implant length may also influence the outcome of immediate implant loading. For every $3 \mathrm{~mm}$ increase in length, the surface area of a cylinder-shaped implant increases by an average of 20-30\% (Misch I999b). One study has reported $50 \%$ failure rate with immediate loading for implant lengths $\leq$ Io mm (Schnitman et al. I997). The majority of studies have suggested that implants should be $\geq$ Io $\mathrm{mm}$ long to ensure high success rates (Buser et al. I988; Lefkove \& Beals I990; Tarnow et al. I997; Horiuchi et al. 2000). Some authors even speculate that it is beneficial to use implants $\geq \mathrm{I} 4 \mathrm{~mm}$ in length and $\geq 4 \mathrm{~mm}$ in diameter for immediate loading (Chiapasco et al. I 997). Nonetheless, data from these studies are based mainly on clinical experience and limited human research. Therefore, the critical length and diameter of immediately loaded implants remains to be determined.

\section{Occlusion-related factors \\ Quality and quantity of force}

Controlling functional forces is one of the ingredients for obtaining success of immediate implant loading. Sagara et al. (I993) found more crestal bone loss in the loaded I-stage implant group when compared to the 2-stage unloaded control group (Sagara et al. I993). It was suggested that the early occlusal loading during healing may account for this observation, since early loading may interfere with the ability of new bone being formed to replace the necrotic bone at the implant/bone interface resulting from surgical trauma (Albrektsson et al. I98I). Vertical forces applied during function are less detrimental to implant stability rather than oblique or horizontal forces. Therefore, bruxism/occlusal overload has been considered as a possible contraindication for immediate implant loading due to higher implant failure rates (Balshi \& Wolfinger I997; Jaffin et al. 2000; Colomina 200I). However, Ganeles et al. (200I) reported only I failure due to bruxism out of I6I immediately loaded implants. Unfortunately, there is not enough scientific information to correlate parafunction habits to immediate loading failure. Colomina (200I) reported $97 \%$ of success rate in immediately loaded implants; however, failed implants ( 2 out of 6I) were attributed to occlusal pathology and oral muscular tension. They further speculate that occlusal load control is essential for maintaining success. Future studies in this area are certainly needed to understand the influence of occlusionrelated factors. Nevertheless, it is often suggested that patients with parafunctional habits (e.g. bruxism) should be excluded or at least well informed about potential risks involved when immediate loaded cases are being planned.

\section{Prosthetic design}

Primary stability can be enhanced when cross-arch implant splinting is performed. Therefore, this prosthetic approach is recommended in immediate implant loading (Ledermann I979, I983; Salama et al. I995; Spiekermann et al. I995; Tarnow et al. I997; Randow et al I999). Glantz et al. (I984a, I984b) have demonstrated that the most favorable loading conditions were achieved via rigid fixed devices. Tarnow et al. (I997) used cast metal frame-enforced provisional restoration to ensure optimal stability and a high success rate for immediately loading implants. The authors further suggested that the temporary prosthesis, once inserted, should not be peaked or removed during the healing period to avoid any unnecessary movement.

Several authors have also proposed a Ushaped curved bar with a rigid connection of 2-4 interforaminal implants, with the presumption that it reduces any movement or nonaxial load on implants (Ledermann I979, I983; Salama et al. I995; Spiekermann et al. I995; Tarnow et al. I997). 
Others have avoided using cantilevers in the fixed implant provisional restorations since they increase load to the terminal fixture by 2-fold (Skalak 1985; Brunski I993; Tarnow et al. 1997), while many others have adopted this concept (Randow et al. 1999; Ericsson et al. 200ob; Colomina 200I). Randow et al. demonstrated similar predictability when compared to the traditional 2-stage surgical protocol. In this study, a permanent fixed supraconstruction with bilateral cantilevers corresponding to 2 premolar units was fabricated. This study, however, is based only on an I 8-month observation period. A 'conversion prosthesis' as provisional appliance, modified from the preexisting prosthesis, was also attempted /Colomina 200I). In the case of a misfit, the prosthesis was separated into two or more parts that were again rigidly connected with resin. All the prostheses had two distal extensions from 5 to $15 \mathrm{~mm}$, according to clinical necessities. Ganeles et al. (200I) placed and restored I6I immediately loaded implants with different prosthesis designs (laboratory processed, screw-retained, laboratory-processed cemented, office processed, screwretained and office-processed cemented) and reported no differences among these designs. When reviewing the literature, it seems to suggest that cross-arch splinting as well as potential load and movement caused by prostheses removal should be avoided in immediately loaded implant cases. Careful occlusal analysis, such as assessment of parafunctional habits and distribution of occlusal support by remaining teeth, is also essential when a loading regimen for implants is considered.

\section{Conclusion}

The level of predictability and high success of current implant therapy has provided reasons for reassessing long adopted surgical and prosthetic guidelines. With the trend of shortening treatment time and reducing patient discomfort/inconvenience, immediate loading implants has reemerged as an alternate approach. This treatment approach has been studied and has shown promising and predictable results. However, it is important to note that a meticulous case selection is still needed to integrate this treatment into daily practice. Certain criteria and guidelines have to be followed to avoid any unnecessary failure. Regular maintenance may be another factor to ensure the long-term success of immediately loaded implants. In addition, factors that may influence the outcome of this approach (e.g., surgery-, host-, implant-, and occlusion-related factors) should be considered and analyzed prior to initiation of treatment. Further studies are definitely needed to explore other possible influential factors. The following are the conclusions drawn from current available information:

- Immediate implant loading achieved similar success rates as those reported in the delayed 2-stage approach.

- Primary implant stability is a key factor to consider before attempting immediate implant loading.

- Surgery-, host-, implant-, and occlusionrelated factors may influence the outcomes of immediate implant loading.

- Studies are needed to understand the possibility of immediate implant loading in patients who are diabetics, osteoporotics and smokers as well as those who have other systemic compromising diseases.

- Long-term, prospective studies are still needed to evaluate other potential determining factors on this technique.

\section{Acknowledgements: This paper was partially supported by the University of Michigan, Periodontal Graduate Student Research Fund and a grant from the Swiss National Foundation for Scientific Research. \\ Disclaimers \\ The authors do not have any financial interests, either directly or indirectly, in the products listed in the study.}

\section{Résumé}

Les implants en médecine dentaire sont devenus un processus à succès depuis la découverte des propriétés biologiques du titane. Dans le protocole original, les études avaient prévu une chirurgie en deux étapes avec une guérison de l'implant enfoui et sans charge afin d'avoir une ostéoïntégration prévisible. Cependant, l'inconfort, l'inconvénient et l'anxiété associés à la période d'attente demeuraient un défi tant pour le clinicien que pour le patient. Donc un implant chargé juste après le placement a été étudié et a gagné en popularité auprès des cliniciens. De nombreuses questions en relation avec cette approche restent sans réponse. Le but de cet article de revue est de (I) revoir de manière critique et d'analyser la littérature actuelle dans le domaine de la charge implantaire immédiate et (2) de discuter sur base scientifique des facteurs qui peuvent influencer cette modalité de traitement. La littérature publiée depuis ces 20 dernièrs années a été sélectionnées et revues. Les découvertes de ces études ont été discutées et placées dans des tableaux. Les avantages et les désavantages associés à la charge implantaire immédiate ont été analysés. Les facteurs qui peuvent influencer le succès de la charge immédiate de l'implant, comprenant la sélection du patient, le type de qualité osseuse, la longueur requise de l'implant, la structure micro et macro de l'implant, la dextérité du praticien, la nécessité d'avoir une stabilité primaire, de contrôler les forces d'occlusion et les guides requis pour les prothèses ont été revus et discutés. Différentes études ont montré la possibilité et la prévision de cette technique. Cependant la plupart de ces articles sont basés sur des données rétrospectives ou de cas sans contrôle. Des essais cliniques longitudinaux parallèles prospectifs et randomisés sont essentiellement basés sur des résultats à court terme et des suivis à long terme sont encore rares dans ce domaine. Cependant à partir de la littérature disponible, Il semble que les localisations anatomiques, les modèles d'implant et les lignes directrices imposées par la prothèse sont les clefs influençant le succès. Davantage d'études randomisées, prospectives et longitudinales sont certainement nécessaires avant que cette approche puissent être suivies par tous.

\section{Zusammenfassung}

Eine kritische Uebersicht über die Sofortbelastung bei Implantaten

Hintergrund: Die Implantatzahnmedizin wurde mit der Entdeckung der biologischen Eigenschaften des Titans erfolgreich. Ursprünglich wurde in Studien ein zweizeitiges chirurgisches Vorgehen mit einer belastungsfreien und submukosalen Einheilung postuliert, um eine voraussagbare Osseointegration zu gewährleisten. Jedoch bleibt der mangelnde Komfort, die Unannehmlichkeiten und die Angst in Zusammenhang mit der Wartephase eine Herausforderung sowohl für Patienten als auch für die Behandler. Daher wurde die Belastung der Implantate sofort nach dem Setzen angestrebt und dieses Vorgehen hat bei den Behandlern an Popularität gewonnen. Tatsachen und Fragen in Zusammenhang mit diesem Vorgehen bleiben unbeantwortet. Es ist daher die Absicht dieses Uebersichtsartikels, I) die auf dem Gebiet der Implantatsofortbelastung zur Verfügung stehende Literatur kritisch durchzusehen und zu analysieren und 2) auf der Grundlage wissenschaftlicher Evidenz Faktoren, welche diese Behandlungsmodalität beeinflussen können, zu diskutieren.

Material und Methoden: Die über die letzten 20 Jahre publizierte Literatur wurde ausgewählt und durchgesehen. Die Ergebnisse dieser Studiesn werden diskutiert und in Tabellen zusammengefasst. Die Vor- und Nachteile in Zusammenhang mit der Sofortbelastung von Implantaten werden analysiert. Faktoren, welche den Erfolg der Sofortbelastung von Implantaten beeinflussen könnten wie etwa Patient- 
enauswahl, Art der Knochenqualität, verlangte Länge der Implantate, Mikro- und Makrostruktur der Implantate, Geschicklichkeit des Chirurgen, Notwendigkeit der Primärstabilität / Kontrolle der okklusalen Kräfte und prothetische Richtlinien, werden gründlich analysiert und diskutiert.

Resultate und Schlussfolgerung: Verschiedene Studien zeigen die Machbarkeit und Voraussagbarkeit dieser Technik. Jedoch basieren die meisten dieser Artikel auf retrospektiven Daten oder unkontrollierten Fallpräsentationen. Randomisierte, prospektive, parallele longitudinale Studien am Menschen zeigen nur Resultate über einen kurzen Zeitraum und Langzeitbeobachtungen sind in diesem Gebiet immer noch rar. Trotzdem kann von der zur Verfügung stehenden Literatur die Schlussfolgerung gezogen werden, dass die anatomische Lokalisation, das Implantatdesign und restriktive prothetische Richtlinien wichtige Faktoren sind, die eine erfolgreiche Behandlung beeinflussen. Weitere Studien, mit Vorteil randomisierte, prospektive longitudinale Studien sind sicherlich nötig, bevor dieses Vorgehen routinemässig eingesetzt werden kann.

\section{Resumen}

Antecedentes: Se ha logrado el éxito con la dentistería de implantes con el descubrimiento de las propiedades biológicas del titanio. En el protocolo original, los estudios abogaban por un protocolo quirúrgico de 2 fases para una cicatrización sin cargas y sumergida para asegurar una osteointegración predecible. Sin embargo, la incomodidad, la inconveniencia, y la ansiedad asociada con el periodo de espera continúan siendo un reto tanto para los pacientes como para los clínicos. Por ello, se intentó cargar los implantes inmediatamente tras su coloca- ción y esto ha ganado popularidad entre los clínicos. Todavía quedan temas y preguntas relacionadas con este enfoque que permanecen sin respuesta. Por lo tanto, la intención de este artículo de revisión es (I) revisar y analizar críticamente la literatura disponible en la actualidad en el campo de la carga inmediata de los implantes y (2) discutir, basándose en evidencias científicas, los factores que pueden influir en esta modalidad de tratamiento.

Materiale y Métodos: Se seleccionó y revisó la literatura publicada durante los últimos 20 años. Los hallazgos de estos estudios se discutieron y resumieron en tablas. Se analizaron las ventajas y desventajas asociadas con la carga inmediata de los implantes. Se revisaron a fondo y se discutieron los factores que pueden influir en el éxito de la carga inmediata de los implantes, incluyendo la selección de los pacientes, el tipo de calidad del hueso, la longitud del implante requerida, la micro- y macroestructura del implante, la habilidad quirúrgica, la necesidad de lograr estabilidad/control primario de las fuerzas oclusales y las normas protésicas.

Resultados y Conclusión: Varios estudios han demostrado la viabilidad y predictibilidad de esta técnica. De todos modos, la mayoría de estos artículos están basados en datos retrospectivos o casos sin control. Los experimentos humanos aleatorios, prospectivos, armados paralelamente están basados primariamente en resultados a corto plazo y los seguimientos a largo plazo son todavía escasos en este campo. No obstante, de la literatura disponible, se puede concluir que las localizaciones anatómicas, los diseños de los implantes, y las normas protésicas restrictivas son de una influencia clave para asegurar unos resultados exitosos. Se necesitan, ciertamente, estudios futuros, preferiblemente aleatorios, prospectivos longitudinales antes de que este enfoque pueda ser usado extensamente.
要旨

背景：インプラント歯科は、チタンの生物学的特 性の発見によって成功をおさめてきた。当初の研 究プロトコールでは、予知性の高い骨性統合を達 成するために、埋入後非荷重の治癒期間をおくと いう2 回法の術式が提唱されていた。しかし待機 期間中の不快感、不便、不安感などが患者にも臨 床医にも困難をもたらしていた。その後インプラ ント埋入直後からの荷重が試みられるようになり、 臨床医の間で人気を博しているが、このアプロー チに関する問題点/疑問点は末解決のままである。 本レビュー論文の目的は、1) インプラント即時 荷重の分野で現在出ている文献を批判的に検封し 分析すること、2）科学的なエビデンスに基づい て、この治療方式に影響すると思われる諸要素に ついて考察することであった。

材料と方法: 過去 20 年以上にわたり発表されて きた文献を選択し、検討した。これらの研究所見 を考察し、表にまとめた。インプラント即時荷重 の長所と短所を分析した。患者選択、骨質、イン プラント長、インプラントの微小構造及びマクロ 構造、外科術式、初期固定/咬合力のコントロー ルに対する必要性及び補綴物のガイドラインなど、 インプラント即時荷重の成功に影響しうる諸要素 を徹底的に検討し、考察した。

結果と結論：様々な研究がこのテクニックの有効 性と予知性を示しているが、このような論文の大 半は後乃向きデータあるいは対照無しの症例であ る。無作為、前向き、 2 群以上の縦断的七ト比較 試験は主として短期結果に基づいており、この分 野では長期の追跡調査は依然としてまれである。 しかし、入手しうる文献から考察した限り、解剖 学的な部位、インプラント・デザイン、厳密な補 綴のガイドラインが成功をもたらす鍵を握ってい ると結論しうる。このアプローチを広く取り入れ る前に、さらなる研究、特に無作為、前向き縦断 的研究を行う必要がある。

キーワード：インプラント、即時/早期インプラ ント荷重、骨性統合

\section{References}

Adell, R., Lekholm, U., Rockler, B. \& Brånemark, P.I. (I98I) A I5-year study of osseointegrated implants in the treatment of the edentulous jaw. International Journal of Oral Surgery ro: 387-4I6.

Akagawa, Y., Hashimoto, M., Kondo, N., Satomi, K., Takata, T. \& Tsuru, H. (I986) Initial boneimplant interfaces of submergible and supramergible endosseous single-crystal sapphire implants. Journal of Prosthetic Dentistry 55: 96-Ioo.

Albrektsson, T. (1993) On long-term maintenance of the osseointegrated response. Australian Prosthodontic Journal 7: I 5-24.

Albrektsson, T., Brånemark, P.I., Hansson, H.A. \& Lindstrom, J. (I98I) Osseointegrated titanium implants. Requirements for ensuring a long-lasting, direct bone-to-implant anchorage in man. Acta Orthopaedica Scandinavica 52: I 55-I70.

Albrektsson, T. \& Sennerby, L. (I99I) State of the art in oral implants. Journal of Clinical Periodontology I8: 474-48 I.

Albrektsson, T., Zarb, G., Worthington, P. \& Eriksson, A.R. (I986) The long-term efficacy of currently used dental implants: a review and proposed criteria of success. International Journal of Oral \& Maxillofacial Implants I: I I-25.
Arvidson, K., Bystedt, H., Frykholm, A., von Konow, L. \& Lothigius, E. (I992) A 3-year clinical study of Astra dental implants in the treatment of edentulous mandibles. International Journal of Oral \& Maxillofacial Implants 7: 32 I-329.

Aspenberg, P., Goodman, S., Toksvig-Larsen, S., Ryd, L. \& Albrektsson, T. (I992) Intermittent micromotion inhibits bone ingrowth. Titanium implants in rabbits. Acta Orthopaedica Scandinavica 63: I4I-I45.

Astrand, P., Almfeldt, I., Brunell, G., Hamp, S.E., Hellem, S. \& Karlsson, U. (I 996) Non-submerged implants in the treatment of the edentulous lower jar. A 2-year longitudinal study. Clinical Oral Implants Research 7: 337-344.

Babbush, C.A., Kent, J.N. \& Misiek, D.J. (I986) Titanium plasma-sprayed (TPS) screw implants for the reconstruction of the edentulous mandible. Journal of Oral \& Maxillofacial Surgery 44: 274-282.

Babbush, C.A. \& Shimura, M. (I993) Five-year statistical and clinical observations with the IMZ two-stage osteointegrated implant system. International Journal of Oral \& Maxillofacial Implants 8: 245-253.
Balshi, T.J. \& Wolfinger, G.J. (I997) Immediate loading of Brånemark implants in edentulous mandibles: a preliminary report. Implant Dentistry 6: 83-88.

Becker, W., Hujoel, P.P., Becker, B.E. \& Willingham, H. (2000) Osteoporosis and implant failure: an exploratory case-control study. Journal of Periodontology 7I: 625-63I.

Bijlani, M. \& Lozada, J.L. (I 996) Immediately loaded dental implants - influence of early functional contacts on implant stability, bone level integrity, and soft tissue quality: a retrospective 3- and 6year clinical analysis. International Journal of Oral \& Maxillofacial Implants II: I26-I27.

Brånemark, P.I., Adell, R., Breine, U., Hansson, B.O., Lindstrom, J. \& Ohlsson, A. (1969) Intraosseous anchorage of dental prostheses. I. Experimental studies. Scandinavian Journal of Plastic and Reconstructive Surgery 3: 8I-Ioo.

Brånemark, P.I., Engstrand, P., Ohrnell, L.O., Grondahl, K., Nilsson, P., Hagberg, K., Darle, C. \& Lekholm, U. (1999) Brånemark Novum: a new treatment concept for rehabilitation of the edentulous mandible. Preliminary results from a prospective clinical follow-up study. Clinical Implant Dentistry \& Related Research I: 2-I6. 
Brånemark, P.I., Hansson, B.O., Adell, R., Breine, U., Lindstrom, J., Hallen, O. \& Ohman, A. (I977) Osseointegrated implants in the treatment of the edentulous jaw. Experience from a ro-year period. Scandinavian Journal of Plastic and Reconstructive Surgery Suppl I6: I-I 32 .

Brånemark, P.I., Zarb, G. \& Albrektsson, T. (I985) Tissue-integrated prosthesis: osseointegration in clinical dentistry. Chicago: Quintessence.

Brisman, D.L. (I996) The effect of speed, pressure, and time on bone temperature during the drilling of implant sites. International Journal of Oral \& Maxillofacial Implants II: 35-37.

Brunski, J.B. ( I 993) Avoid pitfalls of overloading and micromotion of intraosseous implants. Dental Implantology Update 4: 77-8I.

Brunski, J.B., Moccia, A.F. Jr, Pollack, S.R., Korostoff, E. \& Trachtenberg, D.I. (I979) The influence of functional use of endosseous dental implants on the tissue-implant interface. I. Histological aspects. Journal of Dental Research 58: I953-I969.

Buchs, A.U., Levine, L. \& Moy, P. (200I) Preliminary report of immediately loaded Altiva Natural Tooth Replacement dental implants. Clinical Implant Dentistry \& Related Research 2: 97-106.

Buser, D., Schenk, R.K., Steinemann, S., Fiorellini, J.P., Fox, C.H. \& Stich, H. (I99I) Influence of surface characteristics on bone integration of titanium implants. A histomorphometric study in miniature pigs. Journal of Biomedical Materials Research 25: 889-902.

Buser, D.A., Schroeder, A., Sutter, F. \& Lang, N.P. (I988) The new concept of ITI hollow-cylinder and hollow-screw implants: Part 2. Clinical aspects, indications, and early clinical results. International Journal of Oral and Maxillofacial Implants 3: I73-I8I.

Chaushu, G., Chaushu, S., Tzohar, A. \& Dayan, D. (200I) Immediate loading of single-tooth implants: immediate versus non-immediate implantation. A clinical report. International Journal of Oral e) Maxillofacial Implants I6: 267-272.

Chiapasco, M., Gatti, C., Rossi, E., Haefliger, W. \& Markwalder, T.H. (I 997) Implant-retained mandibular overdentures with immediate loading. A retrospective multicenter study on 226 consecutive cases. Clinical Oral Implants Research 8: 48-57.

Chiapasco, M., Abati, S., Romeo, E. \& Vogel, G. (200I) Implant-retained mandibular overdentures with Brånemark System MKII implants: a prospective comparative study between delayed and immediate loading. International Journal of Oral and Maxillofacial Implants I6: 537-546.

Chow, J., Hui, E., Liu, J., Li, D., Wat, P., Li, W., Yau, Y.K. \& Law, H. (200I) The Hong Kong Bridge Protocol. Immediate loading of mandibular Brånemark fixtures using a fixed provisional prosthesis: preliminary results. Clinical Implant Dentistry and Related Research 3: I66-I74.

Colomina, L.E. (200I) Immediate loading of implant-fixed mandibular prostheses: a prospective I8-month follow-up clinical study - preliminary report. Implant Dentistry Io: 23-29.

Cooper, L., Felton, D.A., Kugelberg, C.F., Ellner, S., Chaffee, N., Molina, A.L., Moriarty, J.D., Paquette, D. \& Palmqvist, U. (200I) A multicenter
I 2-month evaluation of single-tooth implants restored 3 weeks after I-stage surgery. International Journal of Oral and Maxillofacial Implants I6: I 82-I92.

Corso, M., Sirota, C., Fiorellini, J., Rasool, F., Szmukler-Moncler, S. \& Weber, H.P. (I999) Clinical and radiographic evaluation of early loaded free-standing dental implants with various coatings in beagle dogs. Journal of Prosthetic Dentistry 82: 428-435.

Cross, D.L., Baumhammers, A., Guarlotti, C.A., Ruskin, P.F. \& Molinari, J.A. (I 974) Healed bone over and through three month old size-graded bladevent implants. Journal of Periodontology 45 : 792-796.

Dao, T.T., Anderson, J.D. \& Zarb, G.A. (I993) Is osteoporosis a risk factor for osseointegration of dental implants? International Journal of Oral and Maxillofacial Implants 8: I37-I44.

DeAngelis, V. (I970) Observations on the response of alveolar bone to orthodontic force. American Journal of Orthodontics 58: 284-294.

Engquist, B., Bergendal, T., Kallus, T. \& Linden, U. (I988) A retrospective multicenter evaluation of osseointegrated implants supporting overdentures. International Journal of Oral and Maxillofacial Implants 3: I 29-I 34.

Ericsson, I., Nilson, H., Lindh, T., Nilner, K. \& Randow, K. (2000a) Immediate functional loading of Brånemark single tooth implants. An I8 months' clinical pilot follow-up study. Clinical Oral Implants Research II: 26-33.

Ericsson, I., Randow, K., Nilner, K. \& Peterson, A. (200ob) Early functional loading of Brånemark dental implants: 5-year clinical follow-up study. Clinical Implant Dentistry and Related Research 2: 70-77.

Eriksson, A., Albrektsson, T., Grane, B. \& McQueen, D. (I982) Thermal injury to bone. A vitalmicroscopic description of heat effects. International Journal of Oral Surgery I I: I I 5-I 2 I.

Eriksson, A.R. \& Albrektsson, T. (I983) Temperature threshold levels for heat-induced bone tissue injury: a vital-microscopic study in the rabbit. Journal of Prosthetic Dentistry 50: IOI-I07.

Eriksson, A.R., Albrektsson, T. \& Albrektsson, B. (I984a) Heat caused by drilling cortical bone. Temperature measured in vivo in patients and animals. Acta Orthopaedica Scandinavica 55: 629-63I.

Eriksson, R.A. \& Albrektsson, T. (I984) The effect of heat on bone regeneration: an experimental study in the rabbit using the bone growth chamber. Journal of Oral and Maxillofacial Surgery 42: 705-7 II.

Eriksson, R.A., Albrektsson, T. \& Magnusson, B. (I984b) Assessment of bone viability after heat trauma. A histological, histochemical and vital microscopic study in the rabbit. Scandinavian Journal of Plastic and Reconstructive Surgery I 8: 26I-268.

Evans, G.H., Mendez, A.J. \& Caudill, R.F. (I996) Loaded and nonloaded titanium versus hydroxyapatite-coated threaded implants in the canine mandible. International Journal of Oral and Maxillofacial Implants II: 360-37 I.

Friberg, B., Sennerby, L., Linden, B., Grondahl, K. \& Lekholm, U. (I999) Stability measurements of one-stage Brånemark implants during healing in mandibles. A clinical resonance frequency analysis study. International Journal of Oral and Maxillofacial Surgery 28: 266-272.

Friberg, B., Ekestubbe, A., Mellstrom, D. \& Sennerby, L. (200I) Brånemark implants and osteoporosis: a clinical exploratory study. Clinical Implant Dentistry \& Related Research 3: 50-56.

Fujimoto, T., Niimi, A., Nakai, H. \& Ueda, M. (I996) Osseointegrated implants in a patient with osteoporosis: a case report. International Journal of Oral and Maxillofacial Implants $\mathbf{I}$ : 539-542.

Ganeles, J., Rosenberg, M.M., Holt, R.L. \& Reichman, L.H. (200I) Immediate loading of implants with fixed restorations in the completely edentulous mandible: report of 27 patients from a private practice. International Journal of Oral and Maxillofacial Implants 16: 4I 8-426.

Gatti, C., Haefliger, W., Chiapasco, M. (2000) Implant-related mandibular overdentures with immediate loading: a prospective study of ITI implants. International Journal of Oral and Maxillofacial Implants I5: 383-388.

Gomes, A., Lozada, J.L., Caplanis, N. \& Kleinman, A. (I998) Immediate loading of a single hydroxyapatite-coated threaded root form implant: a clinical report. Journal of Oral Implantology 24: I 59-I 66.

Glantz, P.O., Nyman, S., Strandman, E. \& Randow, K. (I984a) On functional strain in fixed mandibular reconstructions. II. An in vivo study. Acta Odontologica Scandinavica 5: 269-76.

Glantz, P.O., Strandman, E., Svensson, S.A. \& Randow, K. ( 1984 b) On functional strain in fixed mandibular reconstructions. I. An in vitro study. Acta Odontologica Scandinavica 4: 24I-9.

Haider, R., Watzek, G. \& Plenk, H. (I993) Effects of drill cooling and bone structure on IMZ implant fixation. International Journal of Oral and Maxillofacial Implants 8: 83-9I.

Hansson, H.A., Albrektsson, T. \& Brånemark, P.I. (I983) Structural aspects of the interface between tissue and titanium implants. Journal of Prosthetic Dentistry 50: 108-I I3.

Hara, T., Hayashi, K., Nakashima, Y., Kanemaru, T. \& Iwamoto, Y. (I999) The effect of hydroxyapatite coating on the bonding of bone to titanium implants in the femora of ovariectomised rats. Journal of Bone and Joint Surgery - British Volume 8I: 705-709.

Henry, P. \& Rosenberg, I. (I994) Single-stage surgery for rehabilitation of the edentulous mandible: preliminary results. Practical Periodontics and Aesthetic Dentistry 6: 15-22; quiz 24.

Henry, P.J., Tan, A.E., Leavy, J., Johansson, C.B. \& Albrektsson, T. (I997) Tissue regeneration in bony defects adjacent to immediately loaded titanium implants placed into extraction sockets: a study in dogs. International Journal of Oral and Maxillofacial Implants I2: 758-766.

Hobkirk, J.A. \& Rusiniak, K. (I 977 ) Investigation of variable factors in drilling bone. Journal of Oral Surgery 35: 968-973.

Hodosh, M., Povar, M. \& Shklar, G. (1969) The dental polymer implant concept. Journal of Prosthetic Dentistry 22: 37 I-380. 
Horiuchi, K., Uchida, H., Yamamoto, K. \& Sugimura, M. (2000) Immediate loading of Brånemark system implants following placement in edentulous patients: a clinical report. International Journal of Oral $\oplus$ Maxillofacial Implants $\mathbf{5}$ : 824-83o.

Ivanoff, C.J., Grondahl, K., Bergstrom, C., Lekholm, U. \& Brånemark, P.I. (200o) Influence of bicortical or monocortical anchorage on maxillary implant stability: a I 5-year retrospective study of Brånemark System implants. International Journal of Oral and Maxillofacial Implants $\mathbf{5}$ : IO3-IIO.

Jaffin, R.A. \& Berman, C.L. (I99I) The excessive loss of Brånemark fixtures in type IV bone: a 5year analysis. Journal of Periodontology 62: 2-4.

Jaffin, R.A., Kumar, A. \& Berman, C.L. (200o) Immediate loading of implants in partially and fully edentulous jaws: a series of 27 case reports. Journal of Periodontology 7r: 833-838.

Jo, H.Y., Hobo, P.K. \& Hobo, S. (200I) Freestanding and multiunit immediate loading of the expandable implant: an up-to-40-month prospective survival study. Journal of Prosthetic Dentistry 2: I 48 -I 55 .

Lambert, P.M., Morris, H.F. \& Ochi, S. (I997) Positive effect of surgical experience with implants on second-stage implant survival. Journal of Oral and Maxillofacial Surgery 55: I 2-I 8.

Ledermann, P.D. (I979) Stegprothetische Versorgung des zahnlosen Unterkiefers mit Hilfe von plasmabeschichteten Titanischraubenimplanten. Deutsche Zahmärzhiche Zeitchrift 34: 907-9 I I.

Ledermann, P.D. (I983) Sechsjährige klinische Erfahrung mit dem titanplasmabeschichteten ITI-Schraubenimplantat in der Regio interforaminalis des Unterkiefers. Schweizensche Monatsschrift für Zahnmedizin 93: I080-1089.

Lefkove, M.D. \& Beals, R.P. (I990) Immediate loading of cylinder implants with overdentures in the mandibular symphysis: the titanium plasmasprayed screw technique. Journal of Oral Implantology I6: 265-27 I.

Li, D.H., Liu, B.L., Zou, J.C. \& Xu, K.W. (I999) Improvement of osseointegration of titanium dental implants by a modified sandblasting surface treatment: an in vivo interfacial biomechanics study. Implant Dentistry 8: 289-294.

Linkow, L.I., Glassman, P.E. \& Asnis, S.T. (I973) Macroscopic and microscopic studies of endosteal bladevent implants (six month dog study). Oral Implantology 3: 28 I-309.

Listgarten, M.A. \& Lai, C.H. (I975) Ultrastructure of the intact interface between an endosseous epoxy resin dental implant and the host tissues. Journal de Biologie Buccale 3: 13-28.

Lugero, G.G., de Falco Caparbo, V., Guzzo, M.L., Konig, B. Jr \& Jorgetti, V. (2000) Histomorphometric evaluation of titanium implants in osteoporotic rabbits. Implant Dentistry 9: 303-309.

Lum, L.B. \& Beirne, O.R. (I986) Viability of the retained bone core in the core-vent dental implant. Journal of Oral and Maxillofacial Surgery 44: 34I-345.

Malo, P., Rangert, B. \& Dvarsater, L. (2000) Immediate function of Brånemark implants in the esthetic zone: a retrospective clinical study with 6 months to 4 years of follow-up. Clinical
Implant Dentistry and Related Research $\mathbf{2}$ : I38-I46.

Matthews, L.S. \& Hirsch, C. (I972) Temperatures measured in human cortical bone when drilling. Journal of Bone and Joint Surgery American Volume 54: 297-308.

Misch, C.E. (I999a) Bone density: a key determinant for clinical success. In: C.E. Misch, ed. Contemporary implant dentistry, I09-I I 8. Chicago: Mosby.

Misch, C.E. (r999b) Contemporary implant dentistry, and edition. Chicago: Mosby.

Misch, C.E. (I999c) Implant design considerations for the posterior regions of the mouth. Contemporary Implant Dentistry 8: 376-386.

Mori, H., Manabe, M., Kurachi, Y. \& Nagumo, M. (I997) Osseointegration of dental implants in rabbit bone with low mineral density. Journal of Oral and Maxillofacial Surgery 55: 35I-36I; discussion 362 .

Morris, H.F., Manz, M.C. \& Tarolli, J.H. (I997) Success of multiple endosseous dental implant designs to second-stage surgery across study sites. Journal of Oral and Maxillofacial Surgery 55: 76-82.

O'Sullivan, D., Sennerby, L. \& Meredith, N. (2000) Measurements comparing the initial stability of five designs of dental implants: a human cadaver study. Clinical Implant Dentistry and Related Research 2: 85-92.

Piattelli, A., Corigliano, M., Scarano, A., Costigliola, G. \& Paolantonio, M. (I998) Immediate loading of titanium plasma-sprayed implants: an histologic analysis in monkeys. Journal of Periodontology 69: 32 I-327.

Piattelli, A., Corigliano, M., Scarano, A. \& Quaranta, M. (r997a) Bone reactions to early occlusal loading of two-stage titanium plasma-sprayed implants: a pilot study in monkeys. International Journal of Periodontics and Restorative Dentistry I7: I 62-I 69.

Piattelli, A., Paolantonio, M., Corigliano, M. \& Scarano, A. (I997b) Immediate loading of titanium plasma-sprayed screw-shaped implants in man: a clinical and histological report of two cases. Journal of Periodontology 68: 59I-597.

Piattelli, A., Ruggeri, A., Franchi, M., Romasco, N. \& Trisi, P. (I 993) An histologic and histomorphometric study of bone reactions to unloaded and loaded non-submerged single implants in monkeys: a pilot study. Journal of Oral Implantology I9: 314-320.

Piliero, S.J., Schnitman, P., Pentel, L., Cranin, A.N. \& Dennison, T.A. (I973) Histopathology of oral endosteal metallic implants in dogs. Journal of Dental Research 52: I I I7-I I 27.

Randow, K., Ericsson, I., Nilner, K., Petersson, A. \& Glantz, P.O. (I 999) Immediate functional loading of Brånemark dental implants. An I8-month clinical follow-up study. Clinical Oral Implants Research I0: 8-I 5 .

Riggs, B.L. \& Melton, L.J., III (I986) Involutional osteoporosis. New England Journal of Medicine 314: I 676-I 686.

Roberts, W.E. (I993) Fundamental principles of bone physiology, metabolism and loading. In: Naert, I., van Steenberghe, D. \& Worthington, P., eds. Osseointegration and oral rehabilitation. An introductory textbook, I75-170. London: Quintessence.

Roberts, W.E., Smith, R.K., Zilberman, Y., Mozsary, P.G. \& Smith, R.S. (I984) Osseous adaptation to continuous loading of rigid endosseous implants. American Journal of Orthodontics 86: 95-III.

Roberts, W.E., Turley, P.K., Brezniak, N. \& Fielder, P.J. (I987) Implants: bone physiology and metabolism. Canadian Dental Association Journal I 5 : 54-6I.

Romanos, G., Toh, C.G., Siar, C.H., Swaminathan, D., Ong, A.H., Donath, K., Yaacob, H. \& Nentwig, G.H. (200I) Peri-implant bone reactions to immediately loaded implants. An experimental study in monkeys. Journal of Periodontology $\mathbf{7 2}$ : 506-5 I I.

Rosenlicht, J.L. (I993) Advanced surgical techniques in implant dentistry: contemporary applications of early techniques. Journal of Dental Symposia $\mathbf{I}$ : I6-I9.

Rubin, C.T. \& McLeod, K.J. (I994) Promotion of bony ingrowth by frequency-specific, low-amplitude mechanical strain. Clinical Orthopaedics and Related Research 298: I65-I74.

Sagara, M., Akagawa, Y., Nikai, H. \& Tsuru, H. ( I993) The effects of early occlusal loading on onestage titanium alloy implants in beagle dogs: a pilot study. Journal of Prosthetic Dentistry 69: $28 \mathrm{I}-288$.

Salama, H., Rose, L.F., Salama, M. \& Betts, N.J. (I995) Immediate loading of bilaterally splinted titanium root-form implants in fixed prosthodontics - a technique reexamined: two case reports. International Journal of Periodontics and Restorative Dentistry I5: 344-36I.

Satomi, K., Akagawa, Y., Nikai, H. \& Tsuru, H. (I988) Bone-implant interface structures after nontapping and tapping insertion of screw-type titanium alloy endosseous implants. Journal of Prosthetic Dentistry 59: 339-342.

Schatzker, J., Horne, J.G. \& Sumner-Smith, G. (I975) The effect of movement on the holding power of screws in bone. Clinical Orthopaedics and Related Research 257-262.

Schenk, R. \& Hunziker, E.B. (I994) Histologic and ultrastructural features of fracture healing. In: Brighton, C.T., Friedlander, G., \& Lane, J.M., eds., Bone formation and repair, II7-I46. Rosemont: American Academy of Orthopaedic Surgeons.

Schnitman, P.A., Rubenstein, J.E., Whorle, P.S., DaSilva, J.D. \& Koch, G.G. (I988) Implants for partial edentulism. Journal of Dental Education 52: 725-736.

Schnitman, P.A. \& Shulman, L.B. (I980) Dental implants: benefit and risk, Publication 8I-I53 I. Bethesda, MD: US Dept Health and Humans Services, Government Printing Office.

Schnitman, P.A., Wohrle, P.S., Rubenstein, J.E., DaSilva, J.D. \& Wang, N.H. (I997) Tenyear results for Brånemark implants immediately loaded with fixed prostheses at implant placement. International Journal of Oral and Maxillofacial Implants I2: 495-503.

Schroeder, A., van der Zypen, E., Stich, H. \& Sutter, F. (I98I) The reactions of bone, connective tissue, 
and epithelium to endosteal implants with titanium-sprayed surfaces. Journal of Maxillofacial Surgery 9: I 5-25.

Scortecci, G. (I999) Immediate function of cortically anchored disk-design implants without bone augmentation in moderately to severely resorbed completely edentulous maxillae. Journal of Oral Implantology 25: 70-79.

Skalak, R. (I985) Aspects of biomechanical considerations. In: P.I. Brånemark, Zarb, G. \& Albrektsson, T., eds. Tissue-integrated prosthesis: osseointegration in clinical dentistry, II7-I28. Chicago: Quintessence.

Spector, M. (I988) Non-cemented total hip arthroplasty. In: Fitzgerald Jr, R.H., ed. Current concepts of bony ingrowth and remodeling, 69-86. New York: Raven Press.

Spiekermann, H., Jansen, V.K. \& Richter, E.J. (I 995 ) A Io-year follow-up study of IMZ and TPS implants in the edentulous mandible using bar-retained overdentures. International Journal of Oral and Maxillofacial Implants Io: 23 I-243. Strock, A.E. \& Strock, M. (1939) Experimental work on a method for the replacement of missing teeth by direct implantation of a metal support into the alveolus. American Journal of Orthodontics and Oral Surgery 25: 467.
Szmukler-Moncler, S., Salama, H., Reingewirtz, Y. \& Dubruille, J.H. (I998) Timing of loading and effect of micromotion on bone-dental implant interface: review of experimental literature. Journal of Biomedical Materials Research 43: I92-2O3.

Tarnow, D.P., Emtiaz, S. \& Classi, A. (I997) Immediate loading of threaded implants at stage I surgery in edentulous arches: ten consecutive case reports with I- to 5-year data. International Journal of Oral and Maxillofacial Implants I2: 319-324.

Testori, T., Szmukler-Moncler, S., Francetti, L., Del Fabbro, M., Scarano, A., Piattelli, A. \& Weinstein, R.L. (200I) Immediate loading of osseotite implants: a case report and histologic analysis after 4 months of occlusal loading. International Journal of Periodontics and Restorative Dentistry 5: 45 I-9.

Trisi, P., Rao, W. \& Rebaudi, A. (I999) A histometric comparison of smooth and rough titanium implants in human low-density jawbone. International Journal of Oral and Maxillofacial Implants I4: 689-698.

Uhthoff, H.K. (I973) Mechanical factors influencing the holding power of screws in compact bone. Journal of Bone and Joint Surgery - British Volume 55: 633-639.
Wennerberg, A., Albrektsson, T., Andersson, B. \& Krol, J.J. (I995) A histomorphometric and removal torque study of screw-shaped titanium implants with three different surface topographies. Clinical Oral Implants Research 6: 24-30.

Wheeler, S.L. (I996) Eight-year clinical retrospective study of titanium plasma-sprayed and hydroxyapatite-coated cylinder implants. International Journal of Oral and Maxillofacial Implants II: 340-350.

Wiggins, K.L. \& Malkin, S. (1976) Drilling of bone. Journal of Biomechanics 9: 553-559.

Wolfe, L.A. \& Hobkirk, J.A. (I989) Bone response to a matched modulus endosseous implant material. International Journal of Oral and Maxillofacial Implants 4: 3 I I-320.

Yacker, M.J. \& Klein, M. (1996) The effect of irrigation on osteotomy depth and bur diameter. International Journal of Oral and Maxillofacial Implants II: 634-638.

Yamazaki, M., Shirota, T., Tokugawa, Y., Motohashi, M., Ohno, K., Michi, K. \& Yamaguchi, A. (I999) Bone reactions to titanium screw implants in ovariectomized animals. Oral Surgery, Oral Medicine, Oral Pathology, Oral Radiology and Endodontics 87: 4I I-4I8. 